\title{
The Effect of Sargassum Extract on Culture Medium to The Growth of Chaetoceros gracilis
}

\author{
Andi Adam Malik ${ }^{*}$, Khaeruddin and Fitriani \\ Aquaculture Study Program, Muhammadiyah Parepare University, South Sulawesi, Indonesia \\ ${ }^{*}$ Coresponding Author: andiadammalikhamzah@yahoo.co.id \\ Received: 01 November 2017; Accepted: 28 April 2018
}

\begin{abstract}
Andi Adam Malik, Khaeruddin and Fitriani. 2018. The Effect of Sargassum Extract on Culture Medium to The Growth of Chaetoceros gracilis. Aquacultura Indonesiana, 19 (1): 10-14. Hatchery is one of important factors to maximize shrimp production. One of supporting factors is the availability of qualified natural foods in sufficient quantities. The aim of this study was to know the addition effect of extract Sargassum to culture medium for population growth of Chaetoceros gracilis. Culture medium used for microalgae C. grasilis was a 12 liter jar with density of $10^{5}$ cell/mL. The Sargassum extract was obtained by processing Sargassum waste through anaerob fermentation, then was extracted and considered as liquid organic fertilizer. Tested treatment was A $=0 \mathrm{ppm}$ (without Sargassum extract), B $=10 \mathrm{ppm}$ of Sargassum extract, C $=20 \mathrm{ppm}$ of Sargassum extract and $\mathrm{D}=30 \mathrm{ppm}$ of Sargassum extract for three replications. It was found that the population density of $C$. gracilis increased and the highest algae density occurred in treatment $\mathrm{D}$ on day 5 , followed with $\mathrm{C}, \mathrm{B}$ and $\mathrm{A}$, which were $353,433 \mathrm{cell} / \mathrm{mL}, 336,833 \mathrm{cell} / \mathrm{mL}, 308,867 \mathrm{cell} / \mathrm{mL}$ and $244,433 \mathrm{cell} / \mathrm{mL}$. This illustrates that the addition of high doses has affected the population density of microalgae $C$. gracilis.
\end{abstract}

Keywords: Chaetoceros grasilis; Natural feed; Sargassum extract

\section{Introduction}

Hatchery is one of important factor to maximize production of shrimp farming. The needs of seed are increasing along with the shifting of aquaculture technology from extensive to intensive. One of supporting factor for a successful hatchery was feed availability. Qualified and sufficient feed can improve larvae performance. The availability of natural feed is very important, especially on early stage of larvae where the digestive system was not fully developed, therefore the enzyme was supplied externally.

Natural feed has characteristics such as high nutrition value, easy to process, larvae mouth size, and the ability to reproduce rapidly. Monitoring of cell growth is heavily required in the phytoplankton culture, as well as the quality and the quantity. The phytoplankton varies in growth depend on the culture condition (water quality, light and temperature), inoculant, nutrients, technical skill and species (Liao et al., 1983).

Chaetoceros grasilis is natural feed mainly used in hatchery units especially at shrimp hatchery because of the its high protein content. The nutrient contents are protein $35 \%$, fat $6.9 \%$, carbohydrate $6.6 \%$ and ash content $28 \%$ (Isnansetyo and Kurniastuty, 1995). Despite of its high nutritional value, problem often happened on the availability of microalgae $C$. grasilis, due to the slow growth rate where population peak occurred at the age of 3 to 6 days (Liao et al., 1983).

Biologically Chaetoceros belong to diatom that lived in marine aquatic environment and the body surface wrapped by silicate shell in regular geometric shape. This species has been widely identified and classified based on the size, shape and structure of the silicate of the shell (Hourmant et al., 2009). Shiraiawa (2003) explained that the increase of nutrient supply can increase organic substance production through photosynthesis and decrease cell size on microalgae Emiliania huxleyi.

Adding of stimulants such as cytokine, auxin, gibberellin and minerals may affect growth rate of microalgae. Sargassum sp. contained organic nutrients and growth stimulants of iron, iodine, vitamin $\mathrm{C}$ and minerals like $\mathrm{Ca}, \mathrm{K}, \mathrm{Mg}$, $\mathrm{Na}, \mathrm{Fe}, \mathrm{Cu}, \mathrm{Zn}, \mathrm{S}, \mathrm{P}$ and $\mathrm{Mn}$ and other minerals. The soaking of Sargassum extract to rice and tomato seeds will increase leave growth and plant height 5-25 times of control (without Sargassum) (Sunarpi et al., 2010).

Coastal farmers applied seaweed manure to many corps as seaweeds contain good amount of nitrogen, potassium and other minerals and trace elements, and also the carbohydrates and other organic matters present in seaweeds helps in altering the nature of soil and improving its moisture retaining capacity (Simpson and Hayes, 
1958). Apart from macro and micro nutrients, seaweeds contains many growth promoting hormones like cytokinin, gibberellins, and auxins (Tay et al., 1987). Seaweed extracts are known to enhance seed germination and growth, increased uptake of nutrients, impart a degree of frost resistance and make plants to withstand better towards phytopathological fungi and insect pests (Bhosle et al.,1975).

Boimin (2009) conducted a study to isolate secondary metabolic in the form of steroid, such as free steroid compound, steroid ester and steroid glycoside from the some species of brown algae in South Sulawesi that are Sargassum siliquosum, Turbinaris spp., Sargassum spp., and Padina spp. Sargassum sp. contained natrium alginate (Na-alginat), laminarin, fucoidan, cellulose, mannitol and antioxidant (polyphenol), iron, iodin, vitamin $\mathrm{C}$ and minerals $\mathrm{Ca}, \mathrm{K}, \mathrm{Mg}, \mathrm{Na}, \mathrm{Fe}, \mathrm{Cu}, \mathrm{Zn}$, $\mathrm{S}, \mathrm{P}, \mathrm{Mn}$ and others. Nutrients contents of dried powder of Sargassum sp. are carbohydrate $17.835 \%$, protein $0.776 \%$ and polyphenol $24.58 \%$ (491.5 $\mathrm{mg}$ ).

Sargassum sp. is one of brown algae that is potential to be developed. Sargassum has been widely used as raw material in food industry, pharmacy, cosmetic, feed, fertilizer, textile, paper and many more (Yunizal, 2004). The used of Sargassum for animal feed was reported able to improve meat texture compared to feed that has no Sargassum. This happened because of high minerals content. Sargassum sp. also contains auxin, giberelin and cytokine which have roles as growth stimulant (Kusumaningrum et al., 2007).

Two seaweed species Sargassum and Sapthoglossum in the form of organic fertilizer, regarding stimulator of seed germination and growth parameters (shoot) index as well as enhancer of biochemical attributes of both pulses. Highest growth rate in both leguminous species were observed treated with $3 \mathrm{gm}$ and $6 \mathrm{gm}$ of seaweed dried organic fertilizer. And the lowest growth index was found at $12 \mathrm{gm}, 15 \mathrm{gm}$ and $19 \mathrm{gm}$ of seaweed fertilizer. Therefore results showed that $3 \mathrm{gm}$ and $6 \mathrm{gm}$ treatment were more suitable for plant growth as compared to other treatments (Akhtar et al., 2014).

Fertilizer is a substance that contains numbers of nutrients required by the plants. Fertilization defined as an effort to add nutrients to the plants in order to support their survival (Sutejo, 2002). Liquid organic fertilizer is an organic hydrolysis substance containing N, P, K and micro elements and very useful for plants (Parnata, 2004). The concentration of nitrogen and phosphorus in culture media has a fundamental and direct influence on microalgae growth, besides being closely related to lipid accumulation (Lee et al., 2013).

In other study, Sipaúba-Tavares et al. (2017) was found that growth rate, macrominerals, micro-nutrients and nutritional values were similar to commercial culture medium in the media with inorganic fertilizer and macrophyte. The biological indexes of microalgae were not influenced by weekly differences during the study period. Although lipid contents, nitrogen and growth rate of $A$. gracilis were higher in inorganic fertilizer and macrophyte media; $\mathrm{Mn}, \mathrm{B}, \mathrm{Cu}, \mathrm{S}$, dry matter, ash content, cell volume, Total organic crbon (TOC) and total length were similar among the media used. The same high cell density $25 \times 10^{5}$ cells $/ \mathrm{mL}$ was obtained in NPK and in pure commercial medium or conventional culture medium $\left(\mathrm{CHU}_{12}\right)$, medium respectively after 11 and 14 days cultivation.

Culture medium conditions such as temperature, light, $\mathrm{pH}$ and nutrients, affect not only photosynthesis and productivity of microalgae cells but also influence the activity of cell metabolism and its composition (Huang et al., 2013). Based on above facts, there was a need to conduct a study on the addition of Sargassums extract to the culture medium to the growth of Chaetoceros gracilis population. The aim of this study was to determine the effect of addition Sargassum extract on culture medium to the growth of microalgae $C$. gracilis population, and to find out the dose for Sargassum extract which give highest density of microalgae $C$. gracilis. This research will provide useful information on the effect of addition Sargassum extract to the culture medium of $C$. gracilis in order to ensure the availability of natural feed in shrimp hatchery.

\section{Materials and Methods}

The research was conducted in Benur Bagindo Utama (BBU) of the District Suppa, Pinrang Regency of South Sulawesi Province, Indonesia. Tools for this research were plastic jar $12 \mathrm{~L}$ for culture, aerator, thermometer, $\mathrm{pH}$ meter, and hand refraktometer.

\section{Preparation of Sargassum extract (seaweed liquid fertilizer)}

Seaweed Sargassum sp. washed with water to remove mud, sand, salt, clam shells and other impurities. After washing, seaweed was chopped with $\pm 5 \mathrm{~cm}$ and then milled until crushed and then put into the composter drum. To accelerate 
the decomposition process, an $\mathrm{EM}_{4}$ starter containing Lactobacillus actinomycetes bacteria was used. $\mathrm{EM}_{4}$ is diluted to $2 \%$. After that sprayed into the seaweed while stirring until evenly $( \pm 200 \mathrm{~mL}$ of solution for $10 \mathrm{~kg}$ of seaweed). Furthermore, the composter closed tightly, then let stand for 30 days to produce liquid seaweed fertilizer. The composting process is done in semi-anaerob condition by using aeration pipe contained in drum composter (Zakaria, 2018). The chemical composition of Sargassum were showed at Table 1.

Table 1. Chemical Composition of Sargassum

\begin{tabular}{cc}
\hline Chemical Composition & Percentage (\%) \\
\hline Carbohydrate & 19.06 \\
Protein & 5.53 \\
Fat & 0.74 \\
Water & 11.71 \\
Ash & 34.57 \\
Raw Fiber & 28.39 \\
\hline
\end{tabular}

\section{Chaetoceros species}

Chaetoceros used in this research was $C$. grasilis derived from the stock of pure culture at water quality laboratory of BRPBAP Siddo-Barru. The medium used for optimal growth was water with salinity of 30 ppt. Period of lighting based on Lopes et al., (2008) was 24 hours light with TL 40 watt as source of light. Type of fertilizers used for $C$. gracilis growth and the doses are showed in Table 2. Sargassum extract was obtained by processing Sargassum waste trough anaerob fermentation, then was extracted, and considered as liquid organic fertilizer.

Table 2 . C. Grasilis fertilizer

\begin{tabular}{llc}
\hline No & \multicolumn{1}{c}{ Fertilizer } & Dose $(\mathrm{ppm})$ \\
\hline 1. & $\mathrm{NaNo}_{3}$ & 100 \\
2. & $\mathrm{NaH}_{2} \mathrm{PO}_{4}$ & 10 \\
3. & $\mathrm{FeCl}_{3}$ & 1.3 \\
4. & EDTA & 10 \\
5. & Silicate & 15 \\
\hline
\end{tabular}

\section{Research Procedure}

\section{Container and medium preparation}

The jars that will be used for culture was filled with with water and being aerated. The water was sterilized with chlorine at concentration $10 \mathrm{ppm}$ and later with sodium thiosulfate at concentration of $5 \mathrm{ppm}$. Fertilizers were added to all treatments for pure culture (Tabel 2). Microalgae $C$. gracilis were inserted at $100,000 \mathrm{cell} / \mathrm{mL}$. Extract of Sargassum were added to all treatments each with different doses. Daily monitoring on the growth conducted until last day of the research.

\section{Experimental Design}

Each of tested treatments was replicated 3 times with 4 types of treatments. Experimental design used for this research was Complete Randomized Design.

1. Treatment A: 0 ppm

(kontrol-without Sargassum extract)

2. Treatment B : 10 ppm of Sargassum extract

3. Treatment C: $20 \mathrm{ppm}$ of Sargassum extract

4. Treatment D : $30 \mathrm{ppm}$ of Sargassum extract

The placement of each design units are assigned randomly as shown in Figure 2. Algae growth and water qualities (temperature, $\mathrm{pH}$ and salinity) were observed and recorded every day.

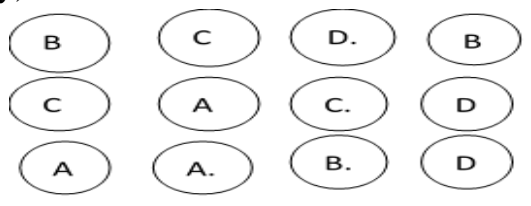

Figure 2. Experiments Layout

\section{Data Analysis}

The data collected were presented in graphs and tabulation, furthermore the effect on each treatment were analyzed with ANOVA using SPSS version 12 for Windows. Graphs and tabulation were presented using Microsoft Excel 2007.

\section{Population Increase}

The increasing population of $C$. grasilis was determined by measuring population growth calculated from subtracting the final population size with initial population size (Daintith, 1993):

$$
\mathrm{N}=\frac{\mathrm{Nt}-\mathrm{No}}{\mathrm{t}}
$$

Where: $\mathrm{N}=$ Population Growth

No $=$ Initial population size $($ cell $/ \mathrm{mL})$

$\mathrm{Nt}=$ Population size at time ' $\mathrm{t}$ ' (cell $/ \mathrm{mL})$

$\mathrm{t}=$ Time (day)

\section{Results and Discussion}

\section{The Growth of Chaetocetos gracilis}

The result showed that the growth rate of microalgae $C$. gracilis on various concentrations of Sargassum extract were increased with increasing concentration of Sargassum extract (Figure 3). The highest growth rate was found on treatment D (30 ppm), followed by C (20 ppm), B (10 ppm) and A (without Sargassum fertilizer). 


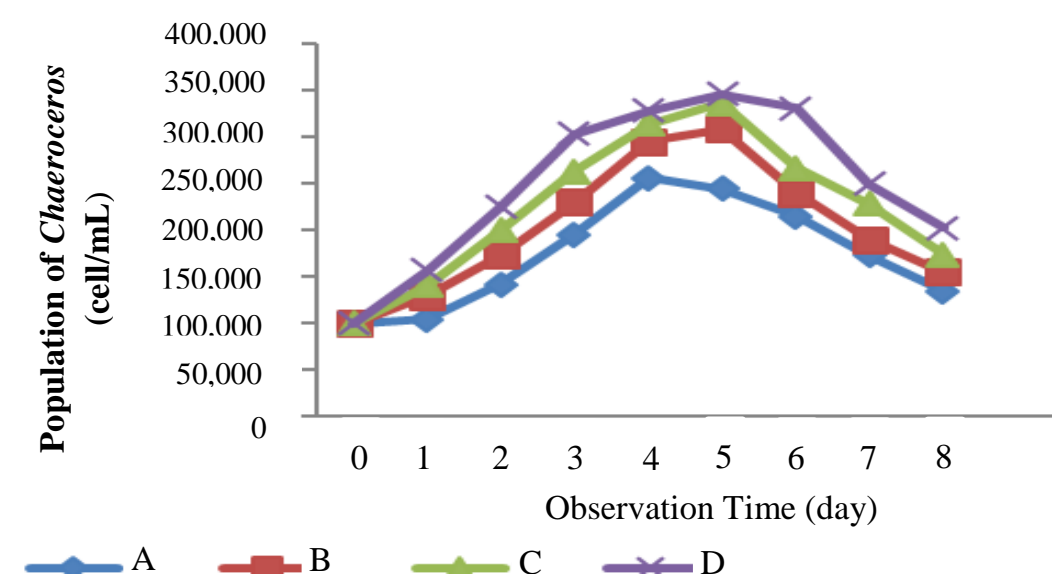

Note. A=Without Sargassum, B=10 ppm, C=20 ppm, D=30 ppm

Figure 3. Growth rate of $C$. grasilis on various Sargassum sp. Concentration

Fertilizer at Culture Medium

Based on Figure 3, the population growth tent to increase with increasing concentration of Sargassum extract. The highest density occurred in treatment $\mathrm{D}$ on day 5 , followed by $\mathrm{C}, \mathrm{B}$ and $\mathrm{A}$ at $353,433 \mathrm{cell} / \mathrm{mL}, 336,833 \mathrm{cell} / \mathrm{mL}, 308,867$ cell $/ \mathrm{mL}$ and 244,433 cell $/ \mathrm{mL}$. The decrease of growth rate started to appear on the day 5 at treatment $\mathrm{A}$, while the decrease of treatments $\mathrm{B}$, $\mathrm{C}$ and $\mathrm{D}$ appeared at day 6 to 8 .

Result of Analysis of Variance (ANOVA) showed that the increase in concentration of Sargassums extract was significant $(\mathrm{P}<0.05)$ to the growth of microalgae $C$. gracilis. The Tukey Test on each treatments showed that treatment A was considered significance $(\mathrm{P}<0.05)$ against treatments $\mathrm{B}, \mathrm{C}$ and $\mathrm{D}$, while $\mathrm{B}, \mathrm{C}$ and $\mathrm{D}$ were not significant $(\mathrm{P}>0.05)$.

The addition of Sargassum extract to the culture medium at treatment $\mathrm{B}, \mathrm{C}$ and D stimulated the growth of microalgae $C$. gracilis compared to treatment A (no LOF Sargassum). This happened because Sargassums extract was an important growing factor for Chaetoceros for its high nutritional content. The addition of growth stimulant substance such as cytokinin, auxin and gibbereline and minerals could affect the growth rate of microalgae. Sargassum sp. contained organic nutrients and iron as growth stimulant, iodine, vitamin $\mathrm{C}$ and minerals such as $\mathrm{Ca}, \mathrm{K}$, $\mathrm{Mg}, \mathrm{Na}, \mathrm{Fe}, \mathrm{Cu}, \mathrm{Zn}, \mathrm{S}, \mathrm{P}, \mathrm{Mn}$ and others. Immersing Sargassum extract to rice and tomato seeds can increase the growth of the leave and height 5-25 times compare to control (without Sargassum) (Sunarpi et al., 2010).

At the beginning of inoculation until day3 the growth were relatively fast especially on culture medium with Sargassum extract. The decline in population growth started on day 5 on treatment A, while at treatment B, C and D appeared at day 6 until last day of research. This is happened because of the reduction of concentration of nitrogen, phosphor and silicate used for grow and the cells were getting older making cell division were getting slow and even terminated. According to Liao et al. (1983) and Godinez et al. (2000) that $C$. gracilis population declining were caused by several factors, 1) limited nutrients, 2) high $\mathrm{pH}$ level in the water that blocked $\mathrm{CO}_{2}$ diffusion, 3) Cell plasmolysis, and 4) An aggregation that increase the sink rate. Wijanarko et al. (2004) mentioned that cell activities are higher at the beginning and overtime slowing down especially at saturated carbohydrate condition. The change of carbohydrate on the cell into organic substance lead to the decrease of concentration of culture medium.

\section{Parameter of Water Quality}

The result of water quality test during the research presented in Table 3 .

Table 3. Averaged range of water quality test

\begin{tabular}{lcccc}
\hline \multirow{2}{*}{ Parameter } & \multicolumn{4}{c}{ Treatment } \\
\cline { 2 - 5 } & $\mathrm{A}$ & $\mathrm{B}$ & $\mathrm{C}$ & $\mathrm{D}$ \\
\hline Temperature & $26-32$ & $26-32$ & $26-33$ & $26-33$ \\
$\left({ }^{\circ} \mathrm{C}\right)$ & 30 & 30 & 30 & 30 \\
$\begin{array}{l}\text { Salinity (ppt) } \\
\text { pH }\end{array}$ & $7.0-9.5$ & $7.0-9.5$ & $7.0-9.5$ & $7.0-9.5$ \\
\hline
\end{tabular}

The table shown the scores were still in the optimal range for microalgae growth. Temperature are around $26-33^{\circ} \mathrm{C}$ still considered under tolerant range, it consistent with Cotteau (1996) that almost all phytoplankton are tolerant to temperature range of $16-36^{\circ} \mathrm{C}$. Salinity was measured at $30 \mathrm{ppt}$ in each treatment. 


\section{Conclusion}

The addition of Sargassum extract into culture medium affected population growth of $G$. gracilis. Highest density of $C$. gracilis found at the addition of $30 \mathrm{ppm}$ of Sargassum extract. To increase the density of microalgae $C$. gracilis in culture medium, it suggested adding Sargassum extract of $30 \mathrm{ppm}$. Further research on the effect of the addition of Sargassum extract to the size and nutrition value should be conducted, as well as study for its application to the shrimp and fish larvae as well. The experiment need to be continued using higher concentration of Sargassum to get the optimum result.

\section{Acknowledgement}

We would like to thank Directorate General for Higher Education, Many thanks to thank you for those who have contributed to the completion in the study.

\section{References}

Akhtar, Y., F. Aziz, F. Jabeen, and S. Arshad. 2014. The effect of seaweed organic fertilizer on growth and biochemical parameters of different flowering plants. International Journal of Advanced Research, 2(9): 935-944.

Bhosle, N.B., V.K. Dhargalkar, and A.G. Untawale. 1975. Effects of seaweed extract on the growth of Phaselous vulgaris L. Indian J.Mar.Sci., 4: 208-210.

Boimin. 2009. Minuman Fungsional Rumput Laut. http:// www.surya.co.id/2009/04/20/minumanfung-sional-rumput-laut.html. [March, 1, 2015].

Cotteau, P. 1996. Microalgae. In: Lavens, P and P. Sorgeloos (Eds.), Manual on Production and Use of Live Food for Aquaculture. FAO Fisheries Technical Paper, Rome, Italia, pp : 8-47.

Daintith, M. 1993. Live Feeds for Marine Aquaculture: A Training Guide. Libraries Australia, pp. 32-33.

Godinez, D., D. Voltolina, M. Nieves, and P. Pina. 2000. Organic fertilizers as nutrient sources for microalgae cultures. Rivista Italiana $d i$ Acquacoltura, 35:75-80.

Hourmant, A., A. Amara, P. Pouline, G. Durand, G. Arzul, and F. Quiniou. 2009 Effect of bentazon on growth and physiological responses of marine diatom: Chaetoceros gracilis. Toxicology Mechanisms and Methods February, 19(2): 109-115.

Huang, X., Z. Huang, W. Wen, and J. Yan. 2013 Effects of nitrogen supplementation of the culture medium on the growth, total lipid content and fatty acid profiles of three microalgae (Tetraselmis subcordiformis, Nannochloropsis oculata and Pavlova viridis). Journal of Applied Phycology, 25(1), 129-137.
Isnansetyo, A. and Kurniastuty. 1995. Teknik Kultur Fitoplankton dan Zooplankton, Pakan Alami untuk Pembenihan Ikan Laut. Karnisius, Yogyakarta, $116 \mathrm{p}$.

Kusumaningrum, I., B.H. Rini, and H. Sri. 2007. Pengaruh Perasan Sargassum. Natural Marine Products Laboratory, Puslitbang Oseanologi, LIPI.

Lee, S.H., C.Y. Ahn, B.H. Jo, S.A. Lee, J.Y. Park, K.G. An, and H.M. Oh. 2013. Increased microalgae growth and nutrient removal using balanced $\mathrm{N}: \mathrm{P}$ ratio in wastewater. Journal of Microbiology and Biotechnology, 23(1), 92-98. PMid:23314374.

Liao, I.H., Su, and J.H. Lin. 1983. Larval Food for Penaeid Prawn. Handbook of Marikultur, CRC Press, Florida. USA.

Lopes, J.E., C.H.G. Scoporo, L.M.C.F. Lacorda and T.T. Franco. 2008. Efect Light Cycle (Night.Day) on $\mathrm{CO}_{2}$ Fixation and Biomass Production by Mikroalga in Photobioreactor Mariculture. CRC Press, Florida, USA.

Parnata A.S. 2004. Pupuk Organik Cair. Agromedia Pustaka, Jakarta.

Shiraiawa, Y. 2003. Physiological regulation of carbon fixation in the photosynthesis and calcification of coccolithophorrids. Comparat Biochemistry and physiology, 136:775-783.

Simpson, K. and S.F. Hayes. 1958. The effect of soil conditioners on plant growth and soil structure. J. Sci. Food Agric., 9: 163-170.

Sipaúba-Tavares, L.H., A.M.D.L. Segali, F.A. Berchielli-Morais, and B. ScardoeliTruzzi. 2017. Development of low-cost culture media for Ankistrodesmus gracilis based on inorganic fertilizer and macrophyte. Acta Limnologica Brasiliensia, 29, e5.

Sunarpi, A., R. Jupri, N.I. Kurnianingsih, A. Julisaniah, and Nikmatullah. 2010. Effect of seaweed extracts on growth and yield of rice plants. Jurnal Bioscience, 2(2):73-77.

Sutejo, M. 2002. Pupuk dan Cara Pemupukan. Rineka Cipta, Jakarta.

Tay, A.A.B., L.M.S. Palni, and J.K. Mac Leod. 1987. Identification of cytokinin glucosides in a seaweed extract. J. Plant Growth Regul., 5: 133-138.

Wijanarko. A, Dianursanti, A.B. Witarto and R.W. Soemantojo. 2004. Effect of photoperiodicity on $\mathrm{CO}_{2}$ fixation by Chlorella vulgaris buitenzorg in bubble colum photobioreactor for food suplement production. Makara Teknologi, 8(2): 35-43.

Yunizal. 2004. Teknik Pengolahan Alginat. Pusat Riset Pengolahan Produk dan Sosial Ekonomi Kelautan dan Perikanan, Jakarta.

Zakaria. 2018. Effect of fermentation time to nutrient composition of liquid seaweed organic fertilizer (Sargassum sp). Skripsi. Muhammadiyah Parepare University, Unpublished. 